\title{
EMPIRICAL DETERMINATION OF THE AVERAGE ANNUAL RUNOFF COEFFICIENT IN THE MEDITERRANEAN AREA
}

\author{
Giovanni Grillone, Giorgio Baiamonte and Francesco D'Asaro
}

Department of Agricultural and Forestry Sciences, University of Palermo, Palermo, Italy

Received 2013-11-19; Revised 2013-11-19; Accepted 2013-12-05

\begin{abstract}
Runoff estimation in ungauged basin is a challenge for the hydrological engineers and planners. For any hydrological study on an ungauged basin, a methodology has to be appropriately selected for the determination of runoff at its outlet. Several methods have been used to estimate the basin runoff production. In this study the empirical Kennessey method to determine average annual runoff coefficient, $\mathrm{RC}$, is tested on 61 Sicilian basins characterized by different climate conditions, surface permeability, mean slope and vegetation cover. A comparison between observed and calculated RC showed that a calibration of the Kennessey model could be necessary. The slight and not satisfying improvement of the calibrated model suggested that the main factors accounted for the Kennessey method could not be enough to describe mean runoff production. So the analysis has been focused on researching empirical relations between RC and other variables which could play a significant role on RC estimation. Finally, the best result on RC estimate was obtained by a simple linear regression for two Sicilian sub-zones, by considering only two main climatic parameters, average annual rainfall depth and average annual temperature.
\end{abstract}

Keywords: Runoff Coefficient, Kennessey Model, Empirical Models

\section{INTRODUCTION}

One of the central problem in hydrology deals with the estimation of average annual runoff production at basin scale. Runoff estimation in ungauged basin is a challenge for the hydrological engineers and planners. The problem becomes much more essential in arid and semiarid regions (D'Asaro and Grillone, 2012) as population increases and land use have continues to change, furthermore, in all those regions, such as Sicily, where the problem of water scarcity is particularly nearby so to be arduous water resources planning.

Several methods are available for estimation of runoff (SCS, 1972). Most of them are based on the estimate of the average annual runoff coefficient, RC. $\mathrm{RC}$ can be defined as the fraction of the average annual precipitation that does not infiltrate into the soil and is not transferred back to the atmosphere through evapotranspiration. Thus, runoff coefficient represents the fraction of the precipitation, in excess of the deep percolation and evapotranspiration, which becomes surface flow and ends up in either perennial or intermittent surface water bodies.

Because of difficulties on modeling spatial variability of topography, geology, soil type and vegetation, as well in climate fluxes such as rainfall, infiltration and evapotranspiration, simple empirical approaches to determine average annual Runoff Coefficient (RC) have been widely applied (Barazzuoli et al., 1988; Santos and Hawkins, 2011). Between the simple empirical models the Kennessey method (Kennessey, 1930) provides RC values by accounting for the main factors wherefrom $\mathrm{RC}$ is influenced: Climate characteristic, surface permeability, mean slope and vegetation cover. After computing a climatic aridity index which, the method involves calculating RC as simple addition of three partial runoff coefficients related to the same components, according to empirical tabled values proposed by Kennessey (1930).

Corresponding Author: Giovanni Grillone, Department of Agricultural and Forestry Sciences, University of Palermo, Palermo, Italy 
This study, after applying Kennessey model for 61 Sicilian basins and after a not satisfying attempt to calibrate it on the base of rainfall and runoff data, aims to provide an empirical and reliable tool to determine average annual runoff coefficient in Sicily.

\section{MATERIALS AND METHODS}

\subsection{Study Area}

The study has been carried out in Sicily, the greatest island of the Mediterranean sea, covering $25,700 \mathrm{~km}^{2}$ (Fig. 1). Sicily is $62 \%$ hilly, principally in the inner areas of the island, $24 \%$ mountainous, mainly in the north and $14 \%$ plain in the coastal areas.

The 1.64 million hectares of agricultural lands are mainly made up of sown lands $(50 \%)$, olive groves $(15 \%)$, orchards $(10 \%$, with prevalence of citrus orchards), vineyards (10\%) (Tudisca et al., 2013).

The mean annual rainfall $\mathrm{P}$ varies in the mountain ranges from 600 to $1,600 \mathrm{~mm}$, whereas in the rest of island $\mathrm{P}$ goes from 300 to $800 \mathrm{~mm}$.

The mean annual temperature $\mathrm{T}$ is approximately $14-15^{\circ} \mathrm{C}$, with lower $\mathrm{T}$ in the mountain ranges $\left(8-13^{\circ} \mathrm{C}\right.$ and even $4-5^{\circ} \mathrm{C}$ at Mt. Etna) and higher $\mathrm{T}$ in the costal and urban areas $\left(18-19^{\circ} \mathrm{C}\right)$ (Agnese et al., 2008; Grillone et al., 2009; 2012).

The study here presented has been carried out for 61 Sicilian gauged basins, quite uniformly distributed all over the region (Fig. 1). Table $\mathbf{1}$ reports main characteristics of the considered basins (D'Asaro and Grillone, 2012). Firstly, each basin has been characterized in terms of climate, morphology, land use; same indications of soil permeability were also available from previous study (Fierotti et al., 1988).

\subsection{Observed Average Annual Runoff Coefficient}

For the 61 considered basins, daily measurements rainfall data and discharge data about in the period 1940 -1997 are available (D'Asaro and Grillone, 2012). Spatial variability of rainfall into the basins has also considered for evaluating annual rainfall depth, by using data collected in 130 pluviometric stations. Observed average runoff coefficient, $\mathrm{RC}_{\mathrm{obs}}$, were computed as the ratio between average annual runoff volume, $\mathrm{Q}$ and average annual rainfall depth, P (Table 1).

\subsection{Kennessey Method}

The Kennessey method let to estimate the average runoff coefficient as a function of three main basin components: slope component, $\mathrm{Ca}$, Permeability component, $\mathrm{Cp}$ and vegetation component, Cv. For each of the three components, partial runoff coefficients have to be evaluated, according to their description reported in Table 2. Partial runoff coefficient is assigned to the basin, once the basin De Martonne aridity index, Ia, is evaluated.

According to the physical meaning of each component, partial runoff coefficient increases with increasing of slope, with decreasing of soil permeability and by passing from forest land use to bare rock.

Furthermore, partial runoff coefficient increases with increasing Ia, i.e., by passing from dry to wet climate basin conditions. Once the partial runoff coefficients are identified, the basin RC is evaluated by their simple addition, after weighting with the basin homogeneous area fractions, where homogeneity has to be intended for each of the 39 classes of Table $2(13 \times 3)$.

To determine the De Martonne aridity index, Ia, for the 61 considered Sicilian basins, Ia map of the Sicilian Region has been extracted from the "Atlante Climatologico della Sicilia" (SIAS, 2002). Ia map has been developed on rainfall data and temperature data from 1965 to 1994, collected for 55 thermo-pluviometric stations e 124 pluviometric stations distributed all over the region.

To determine basins area fractions, for slope component and particularly for the corresponding area fractions associated to the four slope classes of Table 2, $100 \mathrm{~m}$ resolution Digital Elevation Model (DEM) of Sicily has been used.

With reference to the permeability component, it has to be observed that soils of Sicily are characterized by a large variety, going from less to more developed pedologic types (Fierotti et al., 1988). This is due to the different geolithological formations, sedimentary to volcanic to metamorphic, which characterizes the Sicilian Region, as a consequence soil permeability can be considered the most arduous component to determine. For the purpose of this study, in view of the very small spatial scale of this investigation, soil permeability has been roughly estimated by the pedological map mentioned above, by considering a mixed of the qualitative indications there reported (soil depth, soil structure and texture).

Differences in land cover were accounted by the average Normalized Difference Vegetation Index (NDVI) obtained in a previous study for the Sicily, by using NOAA satellite images, for the period 1988-2005 (Bono et al., 2007). Thus, in this study seasonal variability of the vegetation component was not taken into account for the estimation of the average runoff coefficient. Figure 2 reports the four classes of NDVI considered in this study and associated to the vegetation components of the Kennessey method. 
Giovanni Grillone et al. / American Journal of Applied Sciences 11 (1): 89-95, 2014

$\underline{\text { Table 1. Main characteristics of the } 61 \text { Sicilian basins }}$

\begin{tabular}{|c|c|c|c|c|c|c|c|c|c|c|c|}
\hline $\begin{array}{l}\text { ID } \\
\text { Station } \\
\end{array}$ & Station & Watershed & $\begin{array}{l}\text { Area } \\
\left(\mathrm{Km}^{2}\right)\end{array}$ & $\begin{array}{l}\text { River } \\
\text { length }(\mathrm{Km})\end{array}$ & Versant & $\begin{array}{l}\text { Station } \\
\text { altitude }(\mathrm{m})\end{array}$ & $\begin{array}{l}\text { Max basin } \\
\text { altitude }(\mathrm{m})\end{array}$ & $\begin{array}{l}\text { Mean basin } \\
\text { altitude }(\mathrm{m})\end{array}$ & $\begin{array}{l}\text { Mean annual } \\
\text { rainfall } \\
\mathrm{P}(\mathrm{mm})\end{array}$ & $\begin{array}{l}\text { Mean } \\
\text { annual runoff } \\
\mathrm{Q}(\mathrm{mm})\end{array}$ & $\begin{array}{l}\text { Mean annual } \\
\text { temperature } \\
\left({ }^{\circ} \mathrm{C}\right)\end{array}$ \\
\hline 1 & Falcone & Elicona & 54 & 22.2 & 1 & 30 & 1344 & 705 & 987 & 400 & 15.17 \\
\hline 2 & Aculeia & Pollina & 52 & 15.4 & 1 & 330 & 1979 & 1040 & 923 & 246 & 13.30 \\
\hline 3 & Ponte Vecchio & Castelbuono & 99 & 24.8 & 1 & 200 & 1979 & 929 & 831 & 227 & 13.89 \\
\hline 4 & Bivio Cerda & Torto & 414 & 60.8 & 1 & 25 & 1326 & 505 & 588 & 85 & 16.04 \\
\hline 5 & Monumentale & S. Leonardo & 522 & 56.0 & 1 & 2 & 1613 & 580 & 676 & 192 & 15.62 \\
\hline 6 & Lupo & Eleuterio & 10 & 5.4 & 1 & 524 & 1613 & 776 & 791 & 289 & 14.86 \\
\hline 7 & Rossella & Eleuterio & 10 & 4.5 & 1 & 484 & 1029 & 647 & 1103 & 405 & 15.38 \\
\hline 8 & Serena & Valle dell'Acqua & 22 & 9.0 & 1 & 285 & 1029 & 652 & 893 & 216 & 15.33 \\
\hline 9 & Risalaimi & Eleuterio & 53 & 10.5 & 1 & 198 & 1029 & 624 & 715 & 209 & 15.46 \\
\hline 10 & Parco & Oreto & 76 & 13.0 & 1 & 113 & 1333 & 632 & 1007 & 432 & 15.41 \\
\hline 11 & Zucco & Nocella & 57 & 13.8 & 1 & 80 & 1194 & 552 & 990 & 177 & 15.88 \\
\hline 12 & Fellamonica & Iato & 49 & 15.0 & 1 & 210 & 1333 & 594 & 802 & 337 & 15.58 \\
\hline 13 & Taurro & Iato & 164 & 33.5 & 1 & 124 & 1333 & 408 & 656 & 244 & 16.54 \\
\hline 14 & Alcamo Scalo & Fiumefreddo & 273 & 37.0 & 1 & 60 & 825 & 242 & 544 & 115 & 17.33 \\
\hline 15 & Lentina & Forgia & 46 & 14.0 & 1 & 88 & 1008 & 307 & 587 & 115 & 17.01 \\
\hline 16 & La Chinea & Fastaia & 23 & 8.0 & 1 & 210 & 751 & 341 & 544 & 121 & 16.98 \\
\hline 17 & Chinisia & Birgi & 293 & 43.5 & 1 & 4 & 751 & 178 & 504 & 85 & 17.72 \\
\hline 18 & Pozzillo & Delia & 139 & 21.4 & 2 & 93 & 713 & 273 & 728 & 150 & 17.20 \\
\hline 19 & Sparacia & Belice destro & 116 & 32.5 & 2 & 251 & 1233 & 437 & 800 & 233 & 16.32 \\
\hline 20 & Casebalate & Belice sinistro & 342 & 42.5 & 2 & 179 & 1613 & 568 & 626 & 211 & 15.72 \\
\hline 21 & Finocchiara & Senore & 77 & 26.5 & 2 & 126 & 1180 & 411 & 609 & 145 & 16.57 \\
\hline 22 & Ponte Belice & Belice & 807 & 94.2 & 2 & 58 & 1613 & 452 & 650 & 159 & 16.30 \\
\hline 23 & Bruciato & Belici & 131 & 23.0 & 2 & 363 & 1081 & 618 & 564 & 105 & 15.42 \\
\hline 24 & Passofonduto & Platani & 1186 & 76.1 & 2 & 136 & 1580 & 519 & 621 & 109 & 15.96 \\
\hline 25 & Mandorleto & S. Biagio & 74 & 20.0 & 2 & 92 & 607 & 356 & 506 & 81 & 16.79 \\
\hline 26 & Petralia & Imera Merid. & 28 & 8.5 & 2 & 760 & 1912 & 1237 & 805 & 602 & 12.50 \\
\hline 27 & Cinquearchi & Imera Merid. & 545 & 45.0 & 2 & 340 & 1912 & 730 & 681 & 151 & 14.95 \\
\hline 28 & Capodarso & Imera Merid. & 631 & 62.0 & 2 & 270 & 1912 & 691 & 632 & 122 & 15.19 \\
\hline 29 & Donna Paola & Gibbesi & 63 & 15.6 & 2 & 260 & 652 & 437 & 503 & 82 & 16.36 \\
\hline 30 & Drasi & Imera Merid. & 1782 & 125.0 & 2 & 56 & 1912 & 529 & 534 & 106 & 15.95 \\
\hline 31 & Castello & Castello & 26 & 7.7 & 2 & 460 & 1007 & 647 & 542 & 50 & 15.37 \\
\hline 32 & Castelluccio & Tellaro & 102 & 22.5 & 2 & 160 & 770 & 444 & 611 & 59 & 16.32 \\
\hline 33 & Biscari & Simeto & 696 & 60.5 & 2 & 211 & 3274 & 1075 & 681 & 267 & 13.19 \\
\hline 34 & Ponte Gagliano & Salso & 499 & 46.7 & 2 & 375 & 1558 & 790 & 661 & 156 & 14.61 \\
\hline 35 & Giarretta & Simeto & 1832 & 120.0 & 2 & 17 & 3274 & 811 & 633 & 300 & 14.52 \\
\hline 36 & Casecelso & Girgia & 25 & 10.7 & 2 & 340 & 920 & 507 & 733 & 205 & 16.18 \\
\hline 37 & Bozzetta & Dittaino & 79 & 15.2 & 2 & 330 & 1192 & 551 & 808 & 233 & 15.84 \\
\hline 38 & Case Carella & Crisà & 47 & 15.6 & 2 & 331 & 1025 & 611 & 643 & 180 & 15.59 \\
\hline 39 & Chiusitta & Saraceno & 19 & 6.1 & 2 & 1170 & 1754 & 1480 & 1117 & 828 & 11.20 \\
\hline 40 & Moio & Alcantara & 342 & 34.0 & 2 & 510 & 3274 & 1153 & 822 & 228 & 12.74 \\
\hline 41 & Alcantara & Alcantara & 570 & 58.0 & 2 & 20 & 3274 & 949 & 937 & 408 & 13.78 \\
\hline 42 & S. Giacomo & Alcantara & 25 & 7.0 & 2 & 1100 & 1611 & 1228 & 1005 & 679 & 12.38 \\
\hline 43 & Ponte Grande & Isnello & 33 & 10.7 & 1 & 566 & 1979 & 1220 & 841 & 267 & 12.40 \\
\hline 44 & Scillato & Imera Settent. & 105 & 15.7 & 1 & 236 & 1869 & 841 & 733 & 235 & 14.38 \\
\hline 45 & Roccapal. Scalo & Torto & 173 & 31.7 & 1 & 335 & 999 & 572 & 514 & 78 & 15.73 \\
\hline 46 & Vicari & S. Leonardo & 253 & 27.0 & 1 & 250 & 1615 & 675 & 654 & 179 & 15.20 \\
\hline 47 & Milicia & Milicia & 112 & 22.7 & 1 & 130 & 1257 & 496 & 658 & 137 & 16.13 \\
\hline 48 & Sapone & Baiata & 29 & 9.8 & 1 & 44 & 330 & 112 & 478 & 66 & 18.20 \\
\hline 49 & Rinazzo & Chitarra & 37 & 17.8 & 1 & 50 & 368 & 166 & 460 & 68 & 17.74 \\
\hline 50 & Re Giovanni & Gangi & 61 & 11.8 & 2 & 540 & 1333 & 866 & 648 & 171 & 14.28 \\
\hline 51 & Besero & Imera Merid. & 995 & 74.0 & 2 & 230 & 1912 & 636 & 616 & 123 & 15.42 \\
\hline 52 & Monzanaro & Salso & 184 & 24.9 & 2 & 389 & 1660 & 787 & 608 & 123 & 14.64 \\
\hline 53 & Raffo & Salso & 21 & 8.6 & 2 & 685 & 1660 & 1038 & 706 & 378 & 13.41 \\
\hline 54 & S. Pietro & Ficuzza & 128 & 27.0 & 2 & 130 & 692 & 395 & 544 & 41 & 16.65 \\
\hline 55 & Noto & Asinaro & 55 & 14.5 & 2 & 70 & 590 & 362 & 621 & 180 & 16.68 \\
\hline 56 & S. Nicola & Anapo & 82 & 20.8 & 2 & 356 & 986 & 627 & 675 & 275 & 15.45 \\
\hline 57 & Rappis & Trigona & 72 & 23.4 & 2 & 88 & 747 & 466 & 599 & 169 & 16.16 \\
\hline 58 & Serravalle & Troina di Sopra & 157 & 32.0 & 2 & 545 & 1566 & 965 & 671 & 212 & 13.75 \\
\hline 59 & Torricchia & Sciaguana & 67 & 19.6 & 2 & 200 & 824 & 426 & 437 & 45 & 16.38 \\
\hline 60 & Petrosino & Martello & 43 & 11.0 & 2 & 800 & 1800 & 1319 & 866 & 562 & 11.93 \\
\hline 61 & Zarbata & Flascio & 31 & 10.4 & 2 & 970 & 1611 & 1292 & 926 & 637 & 12.09 \\
\hline
\end{tabular}




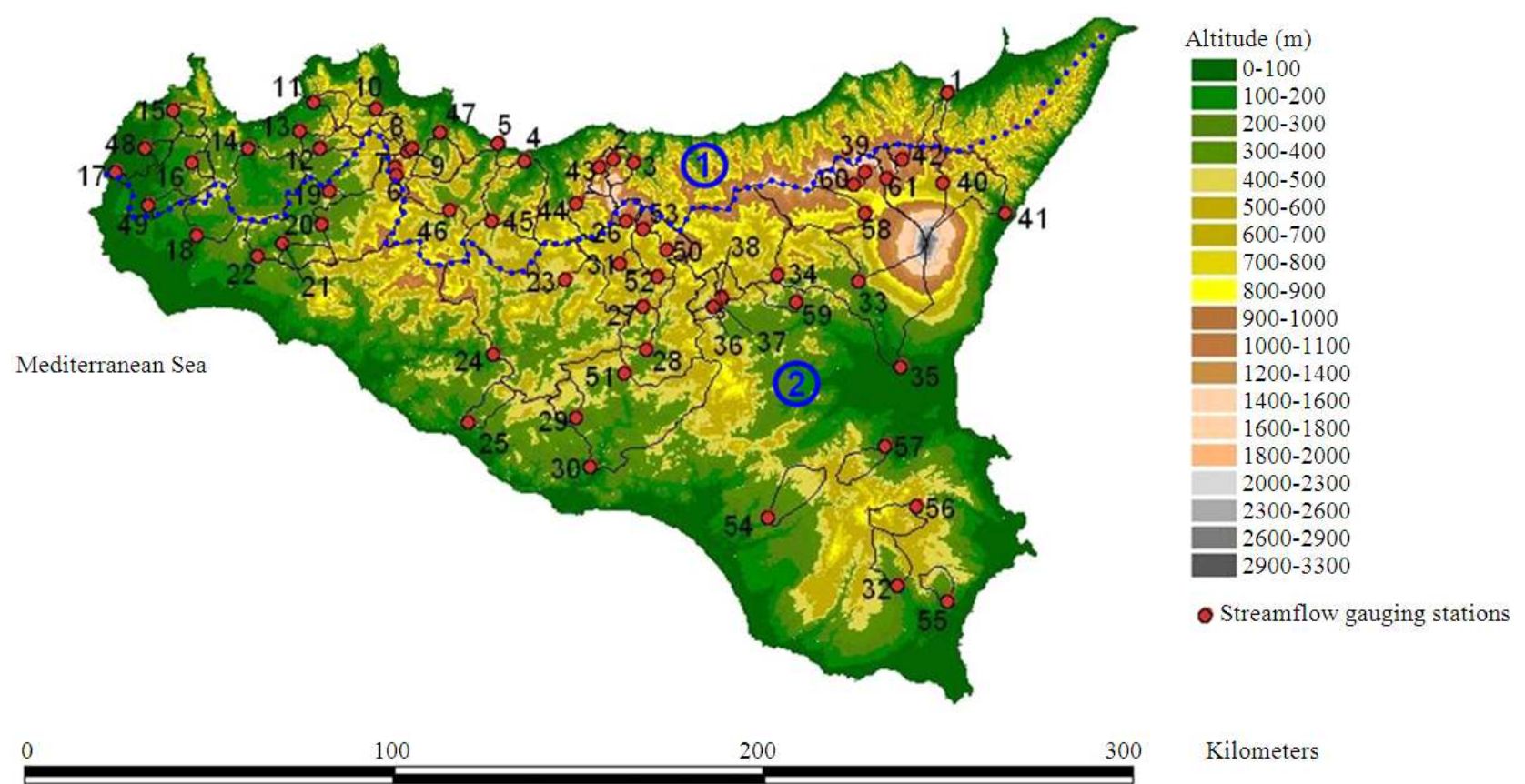

Fig. 1. Sicily region and location of the 61 considered basins. North and south sub-zones, 1 and 2, finally used for the RC linear regression are also indicated

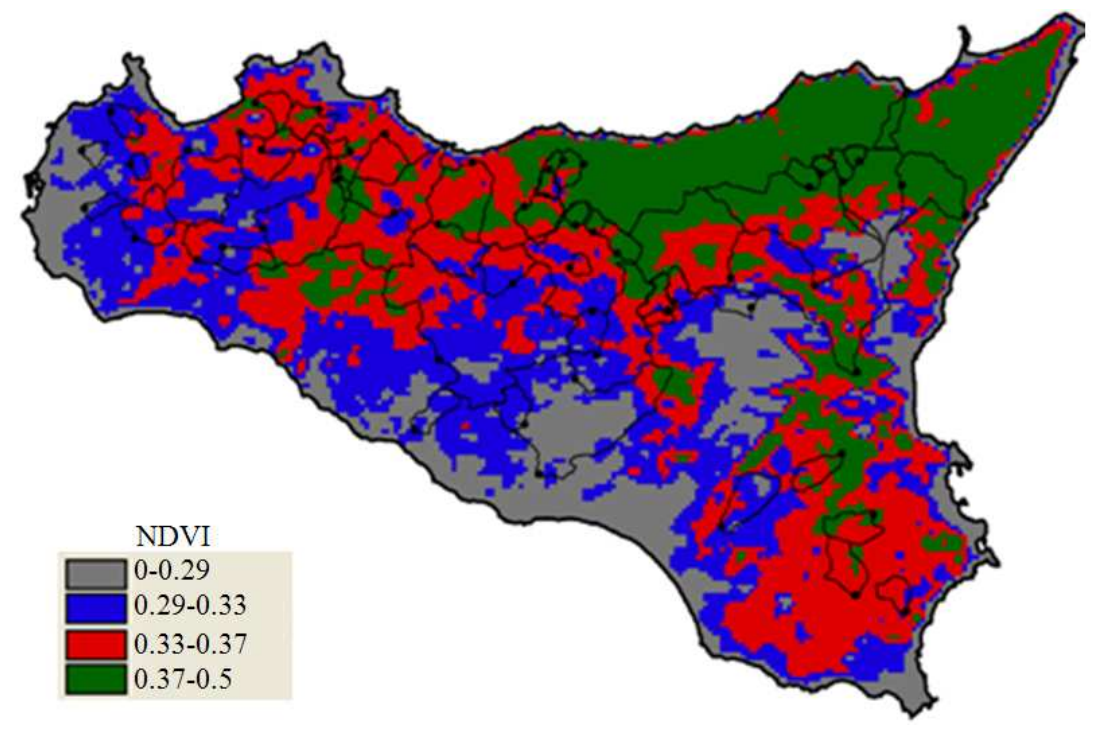

Fig. 2. Classes of NDVI associated to the four vegetation components of the Kennessey method

The determination of the average runoff coefficient of each basin, according to Kennessey method, $\mathrm{RC}_{\mathrm{K}}$, is therefore obtained by adding the partial runoff components of Table 2, weighted with the homogeneous area fractions derived by intersecting the four different thematic maps: Acclivity (Ca), permeability $(\mathrm{Cp})$, vegetation $(\mathrm{Cv})$ and climate condition (Ia). 
Table 2. Partial runoff coefficients of each basin component accounted for the Kennessey method

\begin{tabular}{lllll}
\hline & & $\mathrm{Ia}<25$ & $25<\mathrm{Ia}<40$ & $\mathrm{Ia}>40$ \\
\hline Slope & $>35 \%$ & 0.22 & 0.26 & 0.30 \\
component & $10-35 \%$ & 0.12 & 0.16 & 0.20 \\
$\mathrm{Ca}$ & $3.5-10 \%$ & 0.01 & 0.03 & 0.05 \\
& $<3.5 \%$ & 0 & 0.01 & 0.03 \\
Permeability & Very poor & 0.21 & 0.26 & 0.30 \\
component & Poor & 0.17 & 0.21 & 0.25 \\
$\mathrm{Cp}$ & Moderate & 0.12 & 0.16 & 0.20 \\
& Good & 0.06 & 0.08 & 0.10 \\
& Very good & 0.03 & 0.04 & 0.05 \\
Vegetation & Bare rock & 0.26 & 0.28 & 0.30 \\
component & Grass land & 0.17 & 0.21 & 0.25 \\
$\mathrm{Cv}$ & Farm land & 0.07 & 0.11 & 0.15 \\
& Forest land & 0.03 & 0.04 & 0.05 \\
\hline
\end{tabular}

Table 3. Calibrated runoff coefficients of each component accounted for Kennessey method

\begin{tabular}{lllll}
\hline & & $\mathrm{Ia}<25$ & $25<\mathrm{Ia}<40$ & $\mathrm{Ia}>40$ \\
\hline Slope & $>35 \%$ & 0.20 & 0.20 & 0.20 \\
component & $10-35 \%$ & 0.11 & 0.20 & 0.20 \\
$\mathrm{Ca}$ & $3.5-10 \%$ & 0.03 & 0.03 & 0.20 \\
& $<3.5 \%$ & 0.03 & 0.03 & 0.20 \\
Permeability & Very poor & 0.08 & 0.46 & 0.46 \\
component & Poor & 0.08 & 0.46 & 0.46 \\
$\mathrm{Cp}$ & Moderate & 0.08 & 0.13 & 0.38 \\
& Good & 0.04 & 0.04 & 0.04 \\
Vegetation & Very good & 0.04 & 0.04 & 0.04 \\
component & Bare rock & 0.05 & 0.05 & 0.05 \\
$\mathrm{Cv}$ & Grass land & 0.05 & 0.05 & 0.05 \\
& Farm land & 0.05 & 0.05 & 0.05 \\
& Forest land & 0.05 & 0.05 & 0.05 \\
\hline
\end{tabular}

\subsection{Calibration of the Kennessey Method}

Partial runoff coefficients of the Kennessey method (Table 2) were also calibrated by minimizing the Root Mean Square Error (RMSE) between observed, $\mathrm{RC}_{\mathrm{obs}}$ and calculated $\mathrm{RC}_{\mathrm{K}}$, setting up the above discussed expected trend of partial RC by varying with the classes of each component. Table $\mathbf{3}$, analogously to Table $\mathbf{2}$, reports the partial runoff coefficients obtained by calibrating the Kennessey method based on the observed RC values.

Firstly, Table 3 shows that partial RC is completely unaffected by vegetation component and it is generally weakly influenced by the other components.

Particularly, slope and permeability components result weakly influenced in the down-left side of the table (low Ia and slope values and low Ia and high permeability values), while RC is completely unaffected in the up-right side of the table (high Ia and slope values and high Ia and low permeability values). Calibration results highlights that at basin scale, for Sicily, a spatial averaging effect could probably obscures the important roles of the considered Kennessey components.

\section{RESULTS AND DISCUSSION}

Results of the comparison between observed runoff coefficients $\mathrm{RC}_{\mathrm{obs}}$ and estimated ones by the Kennessey method are presented in Fig. 3. The pairs $\left(\mathrm{RC}_{\mathrm{obs}}, \mathrm{RC}_{\mathrm{K}}\right)$ are almost dispersed around the line of perfect agreement, indicating a clear overestimating/ underestimating of the Kennessey method for the Sicilian environment for small/high RC values.

Figure 3 also reports a comparison between observed $\mathrm{RC}, \mathrm{RC}_{\mathrm{obs}}$ and calculated $\mathrm{RC}$ with the calibrated Kennessey method, $\mathrm{RC}_{\mathrm{K}, \mathrm{c}}$, obtained by using partial runoff coefficients of Table 3. As expected, calibration strongly improves RC estimation (see R and RMSE in Fig. 3), but showed that results are still slights and not at all satisfactory, so to suggest that the components accounted for the RC in the Kennessey method could not be enough to describe mean runoff production. Thus, the analysis has been focused on researching empirical relationships between $\mathrm{RC}_{\mathrm{obs}}$ and other variables which could play a significant role on RC estimation. In particular, average annual rainfall, average annual temperature, average annual evapotranspiration, vegetation indexes, surface basin, main aspect and distance from coast line, mean altitude and height, distance from basin outlet to cost, as regression variables were also considered.

Finally, the best result on RC estimate was carried out by a stepwise regression. In the final relationship, that follows, RC is a function of only the two main climate parameters, average annual rainfall depth, $\mathrm{P}$ $(\mathrm{mm})$ and average annual temperature, $\mathrm{T}\left({ }^{\circ} \mathrm{C}\right)$ Fig. 1:

$\mathrm{RC}=-0.06+0.000411 \mathrm{P}+0.0012 \mathrm{~T}$

for the north sub-zone 1 of Sicily

$\mathrm{RC}=1.09+0.000411 \mathrm{P}-0.0707 \mathrm{~T}$

for the south sub-zone 2 of Sicily

The relationships (1), which show a good fitting of the data with a multiple regression coefficient equal to 0.846 and RMSE $=0.086$ (Fig. 3), can be usefully used in Sicilian ungauged watersheds. Using the maps of average annual rainfall depth, $\mathrm{P}(\mathrm{mm})$ and average annual temperature, $\mathrm{T}\left({ }^{\circ} \mathrm{C}\right)$ furnished by SIAS (2002), the Equations (1) were applied to figure out the RC map for Sicily (Fig. 4). RC values are higher in the north-east part of the island $(0.3 \div 0.5)$, with values higher than 0.6 in areas with higher elevation, whereas lower values are in the south part of the island (Fig. 1 and 4). 
Giovanni Grillone et al. / American Journal of Applied Sciences 11 (1): 89-95, 2014

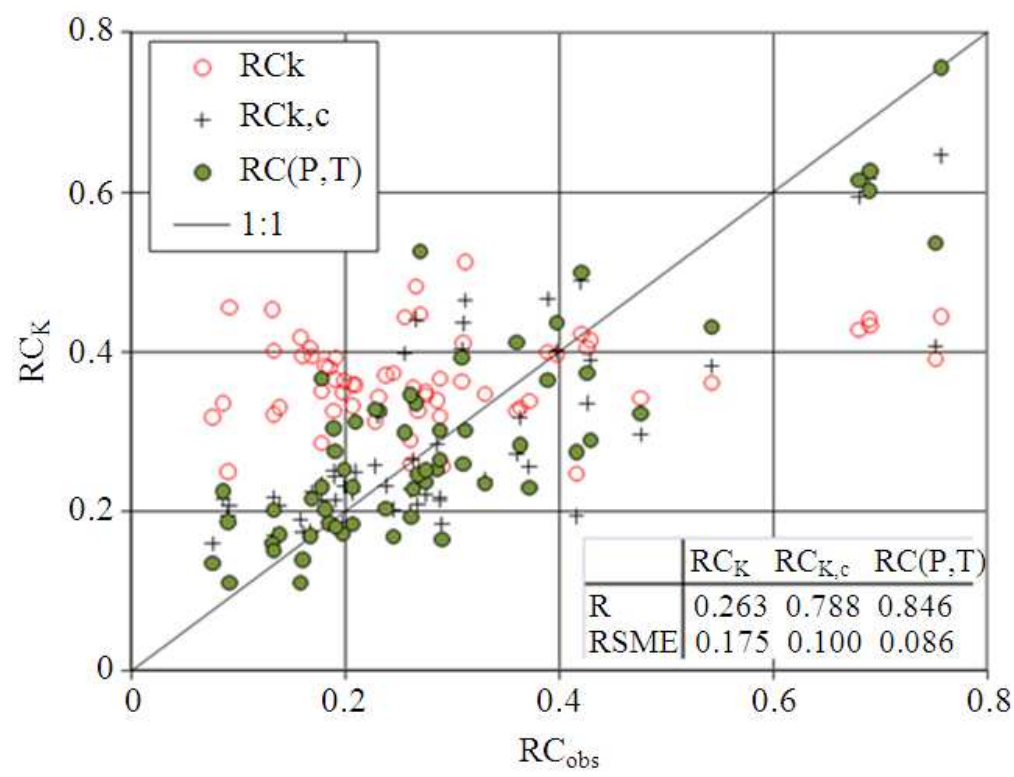

Fig. 3. Comparison between observed RC, RCobs and RC cal-culated by Kennessey method, RCK, by calibrated Kennessey method, RCk,c and by using simple linear regressions (1) as a function of $\mathrm{P}$ and $\mathrm{T}, \mathrm{RC}(\mathrm{P}, \mathrm{T})$, for the considered 61 Sicilian basins. Figure also report the corresponding correlation coefficient, $\mathrm{R}$ and the root mean square error, RMSE

8

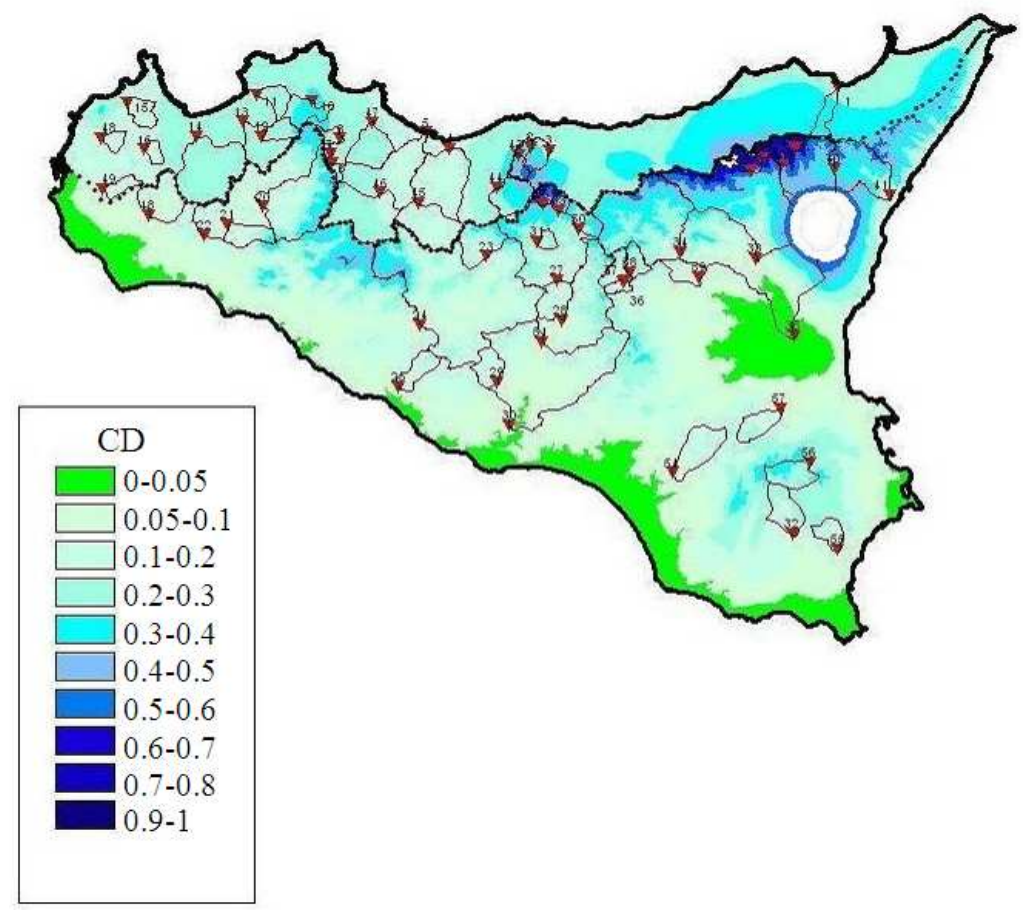

Fig. 4. RC map obtained by Equation (1) 
Future work could improve Equations (1) inserting watersheds' morpho-climatic and hydrologic characteristics here not considered.

\section{CONCLUSION}

After applying Kennessey method to 61 Sicilian basins, a comparison between observed and calculated RC showed that a calibration of the model was necessary. The slight and not satisfying improvement of the calibrated model suggested that the components accounted for the RC estimation could not well explain mean runoff production. So the analysis has been focused on researching empirical relationships between $\mathrm{RC}_{\mathrm{obs}}$ and other variables which could play a significant role on RC estimation. In particular, mean annual precipitation, mean altitude and height, mean potential evapotranspiration, surface, main aspect and distance from coast line, were also considered. Finally, a regional relationship to estimate mean annual runoff production, involving only the two main climate parameters, the average annual rainfall depth and the average annual temperature, is proposed for Sicily Region.

The collecting of watersheds' morpho-climatic and hydrologic characteristics here not considered could improve the RC estimation.

\section{ACKNOWLEDGEMENT}

This study is a result of the full collaboration of all the authors.

\section{REFERENCES}

Agnese, C., G. Grillone and F. D'Asaro, 2008. Comparison of temperature data collected in urban and agricultural areas surrounding. Italian $\mathbf{J}$. Agrometeorol., 13: 48-49.

Barazzuoli, P., S. Izzo, P. Menicori, M. Micheluccini and M. Salleolini, 1988. A new practical aid to regional hydrogeologic planning: The runoff coefficient map. Environ. Manage., 13: 613-622. DOI: 10.1007/BF01874967

Grillone, G., C. Agnese and F. D'Asaro, 2009. Estimation of solar radiation in Sicily by daily data maximum and minimum temperature. Italian $\mathbf{J}$. Agrometeorol., 14: 84-85.
Grillone, G., C. Agnese and F. D'Asaro, 2012. Estimation of daily solar radiation from measured air temperature extremes in the mid-mediterranean area. J. Irrigat. Drainage Eng., 138: 939-947. DOI: 10.1061/(ASCE)IR.1943-4774.0000480

D'Asaro, F. and G. Grillone, 2012. Empirical investigation of curve number method parameters in the Mediterranean area. J. Hydrol. Eng., 17: 1141-1152. DOI: 10.1061/(ASCE)HE.19435584.0000570

Bono, E., F. Capodici, G. Ciraolo, G. La Loggia and A. Maltese et al., 2007. Study of vegetation evolution in Sicily Using Time Series Analysis of Remote Sensing and Climatic Data. In: Remote Sensing for Environmental Monitoring and Change Detection, Owe, M. and C. Neale (Eds.)., International Association of Hydrological Sciences, Wallingford, ISBN-10: 1901502244, pp: 119-130.

Fierotti, G., C. Dazzi and S. Raimondi, 1988. Carta dei Suoli Della Sicilia. 1st Edn., Regione Siciliana, Italy.

Kennessey, B., 1930. Lefoljasy tènyezok ès renenciok. Vizugy, Koziemènyek, Hungary.

Santos, F. and R. Hawkins, 2011. Generalized Mediterranean Annual Water Yield Model: Grunsky's Equation and Long-Term Average Temperature. J. Hydr. Eng., 16: 874-879. DOI: 10.1061/(ASCE)HE.1943-5584.0000402

SIAS, 2002. Sicilian climatologic atlas. Sicilian Informative Agro-meteorological Service, Department of Agriculture of Sicilian Autonomous Region. Italy.

Tudisca, S., A.M. Di Trapani, F. Sgroi and R. Testa, 2013. The cost advantage of Sicilian wine farms. Am. J. Applied Sci., 10: 1529-1536. DOI: 10.3844/ajassp.2013.1529.1536

SCS, 1972. SAS National Engineering Handbook. 1st Edn., Soil Conservation Service, Washington, pp: 26. 